Check for updates

Cite this: RSC Adv., 2021, 11, 18693

Received 28th April 2021

Accepted 12th May 2021

DOI: 10.1039/d1ra03320d

rsc.li/rsc-advances

\section{Structure and absolute configuration assignments of ochracines F-L, chamigrane and cadinane sesquiterpenes from the basidiomycete Steccherinum ochraceum HFG119†}

\author{
Zhen-Zhu Zhao, (D) a Qi-Lu Zhao, ${ }^{a}$ Wei-Sheng Feng, (D) ${ }^{a}$ Hai-Rong He, ${ }^{a}$ Meng Li, ${ }^{a}$ \\ Gui-Min Xue, ${ }^{a}$ He-Ping Chen (DD ${ }^{* b}$ and Ji-Kai Liu ${ }^{* b}$
}

Ochracines $F-L$ (1-7), seven previously undescribed chamigrane and cadinane sesquiterpenoids, together with four known chamigranes were isolated from cultures of the wood-decaying fungus Steccherinum ochraceum HFG119. Ochracines F-L were structurally characterized by extensive analysis of HRMS and NMR spectroscopic data. The relative configurations were assigned through a combination of NOE correlations and J-based configuration analysis (JBCA), while the absolute configurations were determined by X-ray single-crystal diffraction, and calculated methods (ECD, $[\alpha],{ }^{13} \mathrm{C} N M R$ ). All the new isolates were evaluated for their cytotoxicity against five human cancer cell lines HL-60, SMMC-7721, A549, MCF-7, and SW-480, and inhibitory activity on NO production in RAW 264.7 macrophages.

\section{Introduction}

Mushroom-derived sesquiterpenes are recognized as the most structural among the reported mushroom natural products. ${ }^{1}$ Chamigrane sesquiterpenoids featuring a spiro backbone, are rare among higher fungi. ${ }^{2,3}$ Most reported chamigranes are generally produced by the red alga of the genus Laurencia (Family Rhodomelaceae) ${ }^{4-8}$ and endophytic fungi. ${ }^{9-14}$

Our previous chemical study on Stecherinum ochraceum resulted in the isolation of four rare endoperoxide type chamigranes, namely steperoxides A-D, of which steperoxides C and D exhibited antimicrobial activity. ${ }^{2,3}$ Since natural endoperoxides are of special interest, they have attracted and continue to attract considerable attention for their bioactivities. ${ }^{15-17}$ To explore additional peroxy natural products from the cultures of $S$. ochraceum, we scaled up the fermentation, leading to the isolation of five chamigrane-related norsesquiterpene derivatives, ochracines $\mathrm{A}-\mathrm{E},{ }^{\mathbf{1 8}}$ and 9 chamigrane sesquiterpenes including five new ones, namely ochracines F-J (1-5), and two cadinane sesquiterpenes, namely ochracines $\mathrm{K}(6)$ and L (7) (Fig. 1).

${ }^{a}$ School of Pharmacy, Henan University of Chinese Medicine, Zhengzhou 450046, China

${ }^{b}$ School of Pharmaceutical Sciences, South-Central University for Nationalities, Wuhan 430074, China.E-mail: chenhp@mail.scuec.edu.cn; liujikai@mail.scuec.edu.cn $\dagger$ Electronic supplementary information (ESI) available: The 1D \& 2D NMR, HRMS, crystallographic data, and computational details of compounds 1-7. CCDC 1975662. For ESI and crystallographic data in CIF or other electronic format see DOI: $10.1039 / \mathrm{d} 1 \mathrm{ra} 03320 \mathrm{~d}$
As some studies have shown that the production of secondary metabolites is highly dependent on fermentation conditions and modes, ${ }^{19-21}$ the fermentation conditions for producing endoperoxide chamigranes might be special.

On the other hand, the assignment of absolute configurations of small organic natural molecules sometimes is challenging due to the lack of chromophores which result in nonappropriate CD spectrum, and the overlapped proton signals in NMR spectrum causes problems of interpreting the NOE
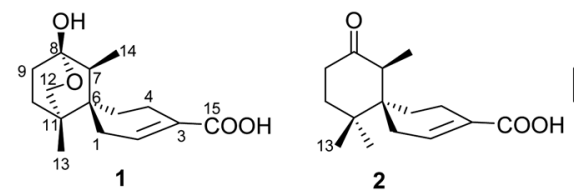

2
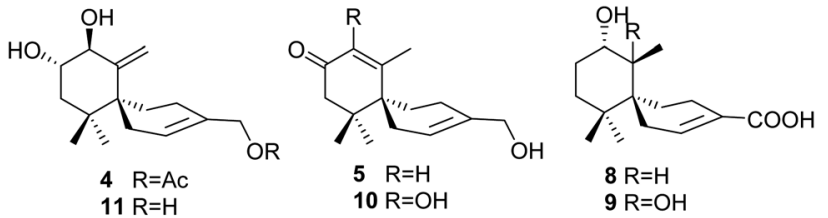

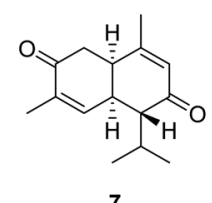

7

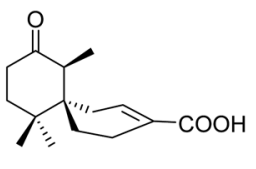

3

$9 \mathrm{R}=\mathrm{OH}$

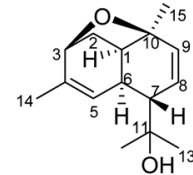

6
Fig. 1 Structures of compounds 1-11. 
correlations, etc. Here, we described the isolation, structure elucidation, and more importantly, the absolute configuration assignment of the sesquiterpenoids from the cultures of the basidiomycete $S$. ochraceum by using combinatorial methods, including $J$-based configuration analysis (JBCA), calculated ECD, $[\alpha]$ and NMR. Moreover, the fermentation conditions for production endoperoxide type are discussed.

\section{Results and discussion}

Ochracine $\mathrm{F}$ (1), colourless needles $(\mathrm{MeOH})$, afforded the molecular formula $\mathrm{C}_{15} \mathrm{H}_{22} \mathrm{O}_{4}$ deduced from the HRESIMS ion at $m / z 289.1408[\mathrm{M}+\mathrm{Na}]^{+}$, requiring five degrees of unsaturation. Combined analysis of ${ }^{1} \mathrm{H},{ }^{13} \mathrm{C}$ NMR data (Tables 1 and 2), and the HSQC spectroscopic correlations disclosed the presence of one singlet methyl, one doublet methyl, six $\mathrm{sp}^{3}$ methylenes [one

Table $1{ }^{1} \mathrm{H}$ NMR data of compounds $1-5(600 \mathrm{MHz})$

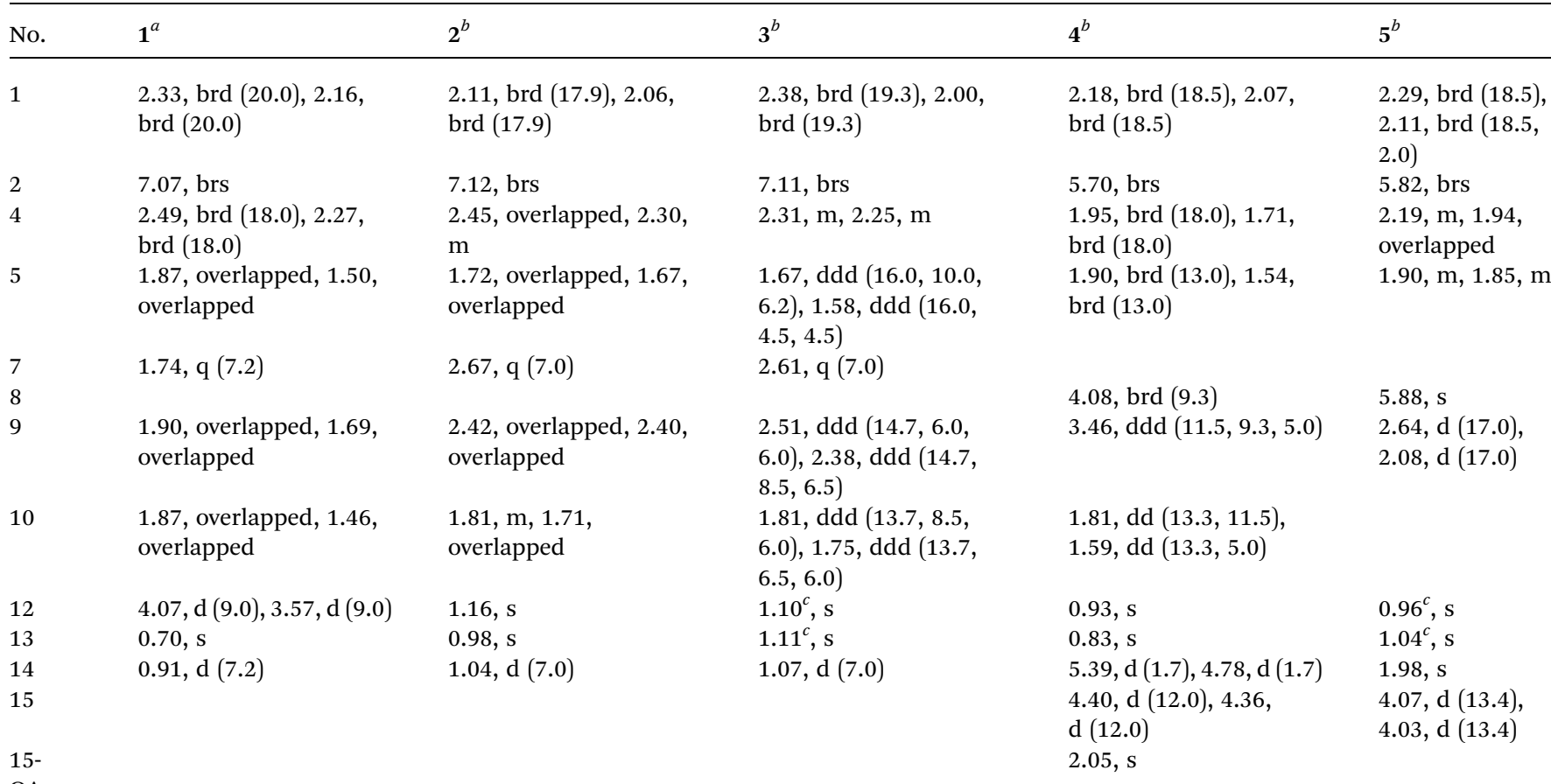

${ }^{a}$ Measured in $\mathrm{CD}_{3} \mathrm{OD} .{ }^{b}$ Measured in $\mathrm{CDCl}_{3} .{ }^{c}$ Interchangeable assignments.

Table $2{ }^{13} \mathrm{C}$ NMR data of compounds 1-7 (150 MHz)

\begin{tabular}{|c|c|c|c|c|c|c|c|}
\hline No. & $\mathbf{1}^{a}$ & $2^{b}$ & $3^{b}$ & $4^{b}$ & $5^{b}$ & $6^{b}$ & $7^{a}$ \\
\hline 1 & 29.4, $\mathrm{CH}_{2}$ & $27.4, \mathrm{CH}_{2}$ & $32.7, \mathrm{CH}_{2}$ & 29.6, $\mathrm{CH}_{2}$ & $27.9, \mathrm{CH}_{2}$ & $40.0, \mathrm{CH}$ & $39.5, \mathrm{CH}$ \\
\hline 2 & 142.4, $\mathrm{CH}$ & $142.4, \mathrm{CH}$ & $141.8, \mathrm{CH}$ & 125.0, CH & 123.5, CH & $35.6, \mathrm{CH}_{2}$ & $40.9, \mathrm{CH}$ \\
\hline 4 & $22.2, \mathrm{CH}_{2}$ & 22.7, $\mathrm{CH}_{2}$ & 22.1, $\mathrm{CH}_{2}$ & $23.8, \mathrm{CH}_{2}$ & $24.0, \mathrm{CH}_{2}$ & 138.4, C & $137.4, \mathrm{C}$ \\
\hline 5 & $31.0, \mathrm{CH}_{2}$ & $28.3, \mathrm{CH}_{2}$ & 23.9, $\mathrm{CH}_{2}$ & 26.6, $\mathrm{CH}_{2}$ & $30.6, \mathrm{CH}_{2}$ & 126.1, CH & 149.2, CH \\
\hline 6 & $39.0, \mathrm{C}$ & $44.5, \mathrm{C}$ & $43.6, \mathrm{C}$ & $45.4, \mathrm{C}$ & $44.0, \mathrm{C}$ & $37.1, \mathrm{CH}$ & $40.2, \mathrm{CH}$ \\
\hline 9 & $28.0, \mathrm{CH}_{2}$ & $37.7, \mathrm{CH}_{2}$ & $37.0, \mathrm{CH}_{2}$ & $73.3, \mathrm{CH}$ & 49.1, $\mathrm{CH}_{2}$ & $136.5, \mathrm{CH}$ & 128.1, CH \\
\hline 10 & $30.6, \mathrm{CH}_{2}$ & $38.2, \mathrm{CH}_{2}$ & 37.1, $\mathrm{CH}_{2}$ & 43.1, $\mathrm{CH}_{2}$ & $198.8, \mathrm{C}$ & $77.4, \mathrm{C}$ & 162.1, C \\
\hline 11 & $35.8, \mathrm{C}$ & $37.5, \mathrm{C}$ & $37.5, \mathrm{C}$ & $37.5, \mathrm{C}$ & $40.6, \mathrm{C}$ & $72.9, \mathrm{C}$ & $28.1, \mathrm{CH}$ \\
\hline 12 & $73.3, \mathrm{CH}_{2}$ & 23.7, $\mathrm{CH}_{3}$ & $25.2, \mathrm{CH}_{3}$ & 24.7, $\mathrm{CH}_{3}$ & 25.0, $\mathrm{CH}_{3}$ & 28.3, $\mathrm{CH}_{3}$ & 21.0, $\mathrm{CH}_{3}$ \\
\hline 13 & $17.7, \mathrm{CH}_{3}$ & $26.2, \mathrm{CH}_{3}$ & 24.6, $\mathrm{CH}_{3}$ & $24.1, \mathrm{CH}_{3}$ & $24.0, \mathrm{CH}_{3}$ & $29.8, \mathrm{CH}_{3}$ & 21.5, $\mathrm{CH}_{3}$ \\
\hline 14 & $13.8, \mathrm{CH}_{3}$ & $11.8, \mathrm{CH}_{3}$ & $12.5, \mathrm{CH}_{3}$ & $109.8, \mathrm{CH}_{2}$ & 24.5, $\mathrm{CH}_{3}$ & 21.5, $\mathrm{CH}_{3}$ & 15.7, $\mathrm{CH}_{3}$ \\
\hline
\end{tabular}

${ }^{a}$ Measured in $\mathrm{CD}_{3} \mathrm{OD} .{ }^{b}$ Measured in $\mathrm{CDCl}_{3}$. 


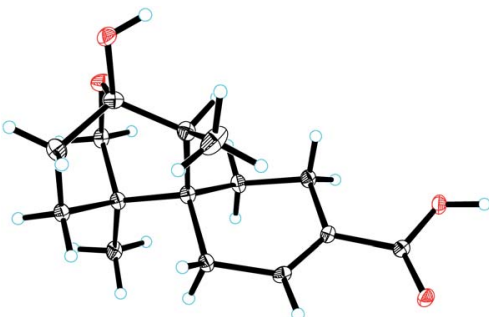

Fig. 2 ORTEP drawing of compound 1.

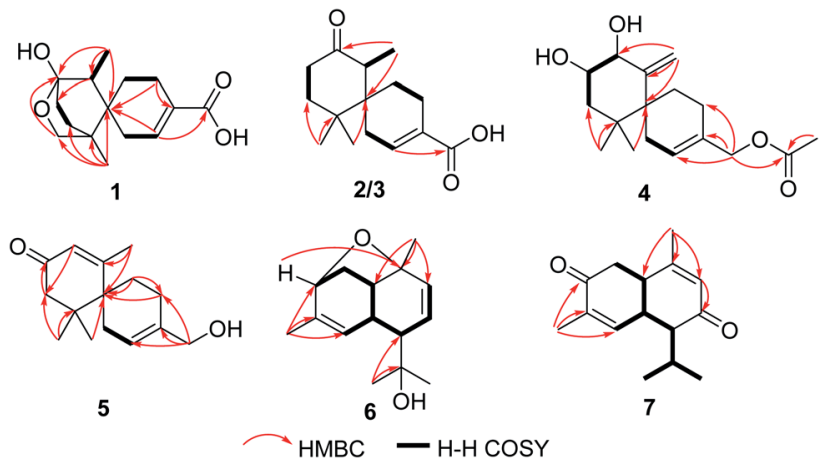

Fig. 3 Selected $\mathrm{HMBC}$ and ${ }^{1} \mathrm{H}-{ }^{1} \mathrm{H}$ COSY correlations of 1-7.
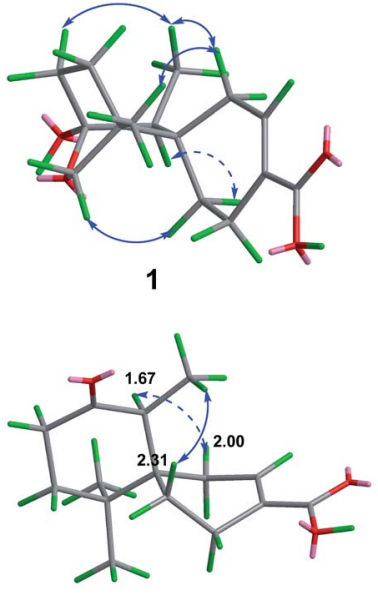

3
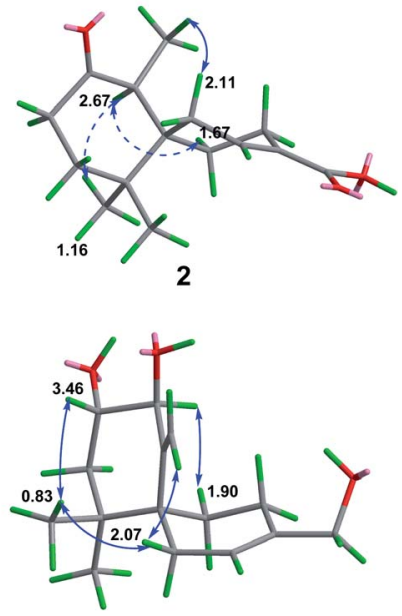

4
Fig. 4 Selected NOE correlations of 1-4.

oxygenated $\left.\left(\delta_{\mathrm{C} / \mathrm{H}} 73.3 / 4.07,3.57\right)\right]$, one $\mathrm{sp}^{3}$ methine, one trisubstituted double bond $\left(\delta_{\mathrm{C} / \mathrm{H}} 142.4 / 7.07 ; \delta_{\mathrm{C}} 131.7\right)$, and four quaternary carbons, including one hemiketal carbon $\left(\delta_{\mathrm{C}} 99.3\right)$ and a conjugated carboxylic carbon $\left(\delta_{\mathrm{C}} 170.8\right)$. The above assignments (an $\alpha, \beta$-unsaturated carboxyl) account for two of five hydrogen deficiencys, indicating that $\mathbf{1}$ is a tricyclic compound. Further analysis of the ${ }^{1} \mathrm{H}^{1}{ }^{1} \mathrm{H}$ COSY spectrum (Fig. 3) established five spin systems of $\mathrm{H}_{2}-1 / \mathrm{H}-2, \mathrm{H}_{2}-4 / \mathrm{H}_{2}-5, \mathrm{H}_{3}$ $14 / \mathrm{H}-7$, and $\mathrm{H}_{2}-9 / \mathrm{H}_{2}-10$. The HMBC spectrum (Fig. 3) showed correlations from $\mathrm{H}_{3}-13$ to $\mathrm{C}-6 / \mathrm{C}-10 / \mathrm{C}-11 / \mathrm{C}-12, \mathrm{H}_{3}-14$ to C-6/C-7/ C-8, and $\mathrm{H}-7$ to $\mathrm{C}-9$, establishing a partial structure of a six- membered ring with a hemiketal (C-8), 12- $\mathrm{CH}_{2} \mathrm{OH}, 13-\mathrm{CH}_{3}$ and $14-\mathrm{CH}_{3}$, and correlations from $\mathrm{H}_{2}-4$ to C-3/C-6, and $\mathrm{H}-2$ to $\mathrm{C}-15$, confirming the presence of a cyclohexene ring with a carboxylic group (15-COOH) substituted at C-3. These two rings share C-6 as the spiro carbon judging from the $\mathrm{HMBC}$ correlations of $\mathrm{H}_{3}-13 / \mathrm{H}_{3}-14 / \mathrm{H}_{2}-4 / \mathrm{H}-2$ to C- 6 . The molecular formula, $\mathrm{C}_{15} \mathrm{H}_{22} \mathrm{O}_{4}$, and the $\mathrm{HMBC}$ correlations from $\mathrm{H}_{2}-12$ to C8 suggested that C- 8 and C-12 are linked through an ether bond, which rendered compound $\mathbf{1}$ a novel chamigrane sesquiterpene featuring a 6/6/6 tricyclic system. As shown in Fig. 4, the relative configuration was determined by NOE correlations. Fortunately, single crystal X-ray analysis using $\mathrm{CuK} \alpha$ radiation not only confirmed the structure validity of $\mathbf{1}$, but also established its absolute configuration (Fig. 2). Moreover, in order to provide integrated data for the structure of this type, experimental CD and calculated ECD spectra of $(6 R, 7 S, 8 S, 11 R)$-1 were carried out (Fig. 5) (ESI†).

Ochracine G (2), $\mathrm{C}_{15} \mathrm{H}_{22} \mathrm{O}_{3}$, had comparable 1D NMR data (Tables 1 and 2) with those of co-isolate merulinol $(8),{ }^{11}$ implying that 2 is a chamigrane sesquiterpene. Analysis of the spectroscopic data showed that $8-\mathrm{CHOH}$ in 8 was oxygenated to a ketone $\left(\delta_{\mathrm{C}} 214.3\right)$ in 2 , which was corroborated by HMBC correlations from $\mathrm{H}_{3}-14$ to C-8 (Fig. 3) and the HRMS result. The relative configuration of 2 was deduced by NOE correlations of $\mathrm{H}_{3}-12\left(\delta_{\mathrm{H}} 1.16\right) / \mathrm{H}-7\left(\delta_{\mathrm{H}} 2.67\right) / \mathrm{H}_{\mathrm{eq}}-5\left(\delta_{\mathrm{H}} 1.67\right)$, and $\mathrm{H}_{3}-14\left(\delta_{\mathrm{H}}\right.$ 1.04) $/ \mathrm{H}_{\mathrm{ax}}-1$ ( $\left.\delta_{\mathrm{H}} 2.11\right)$ (Fig. 4), showing that the relative stereochemistries of 2 are $6 R^{*}$ and $7 S^{*}$.

The molecular formula of ochracine $\mathrm{H}(3), \mathrm{C}_{15} \mathrm{H}_{22} \mathrm{O}_{3}$, is identical with that of 2, implying that they are analogues. The quite similar 1D NMR spectra of 2 and $\mathbf{3}$ (Tables 1 and 2), except for minor differences of chemical shifts of C-1, C-5, and C-6, suggested that they share the same planar structures, but with different configurations, which was further verified by ${ }^{1} \mathrm{H}^{-1} \mathrm{H}$ COSY and HMBC spectra (Fig. 3). The configuration difference of C- 6 between 2 and 3 led to changes of the chemical shifts at C-1, C-5 and C-6, suggesting the chiral carbon C-6 should be $S^{*}$ in 3 rather than the $R^{*}$ in 2 . In the ROESY experiment (Fig. 4), cross peaks of $\mathrm{H}-7\left(\delta_{\mathrm{H}} 2.61\right)$ with $\mathrm{H}_{\mathrm{eq}}-1\left(\delta_{\mathrm{H}} 2.00\right)$, and $\mathrm{H}_{3}-14\left(\delta_{\mathrm{H}}\right.$

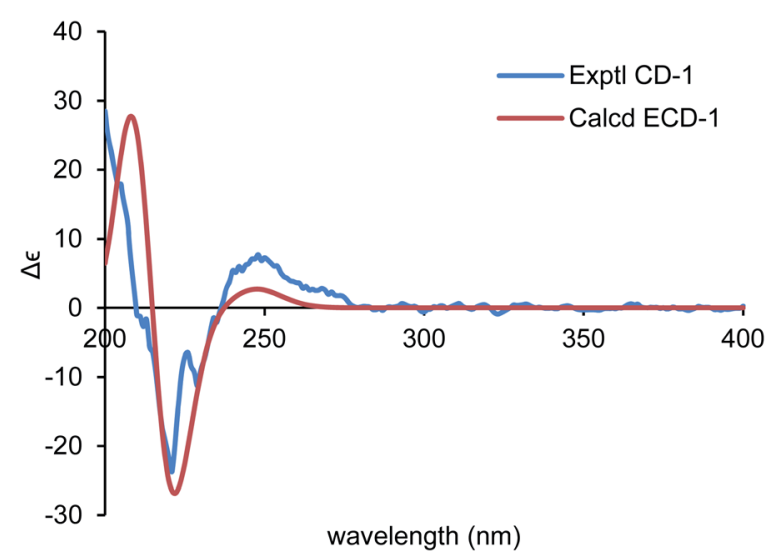

Fig. 5 Comparison of the calculated ECD spectrum for $(6 R, 7 S, 8 S, 11 R)-1(\sigma=0.22 \mathrm{eV}$, UV shift $0 \mathrm{~nm})$ with the experimental spectrum of 1 in $\mathrm{MeOH}$. 


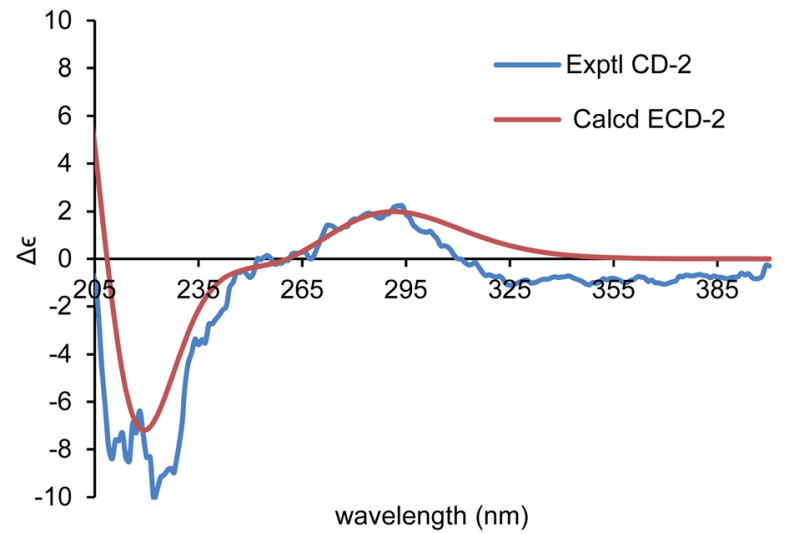

Fig. 6 Comparison of the calculated ECD spectrum for $(6 R, 7 S)-2$ ( $\sigma=$ $0.40 \mathrm{eV}, U V$ shift $-1 \mathrm{~nm}$ ) with the experimental spectrum of 2 in $\mathrm{MeOH}$.

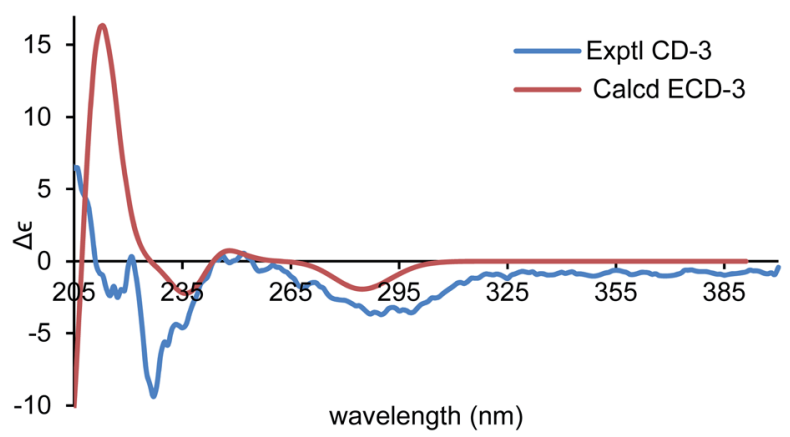

Fig. 7 Comparison of the calculated ECD spectra for (6S,7S)-3 ( $\sigma=$ $0.16 \mathrm{eV}$, UV shift $-8 \mathrm{~nm}$ ) with the experimental spectrum of 3 in $\mathrm{MeOH}$.

1.07) with $\mathrm{H}_{\mathrm{ax}}-5 \quad\left(\delta_{\mathrm{H}}\right.$ 1.67) observed revealed that relative configurations of 2 are $6 S^{*}$ and $7 S^{*}$.

To establish the absolute configurations of 2 and 3, calculated electronic circular dichroisms (ECDs) for $(6 R, 7 S)-2$ and $(6 S, 7 S)-3$ were carried out (ESI $\dagger$ ), respectively. As shown in Fig. 6 and 7 , comparison with the experimental of $(6 R, 7 S)-2$, and $(6 S, 7 S)-3$ with the calculated ones, the calculated ECD spectra of presented good fitting, which are in accord with octant rule to the Cotton effect near $290 \mathrm{~nm}$ observed in the ECD spectra. Thus, the absolute configurations of 2 and 3 were determined with no doubt as suggested above.

Ochracine I (4) had a molecular formula $\mathrm{C}_{17} \mathrm{H}_{26} \mathrm{O}_{4}$ with five degrees of unsaturation. Its ${ }^{1} \mathrm{H}$ and ${ }^{13} \mathrm{C}$ NMR (Tables 1 and 2) data showed a close similarity to those of the co-isolate compound, acaciicolinol F (11). ${ }^{13}$ Analysis of these data indicated that the hydroxyl at C-15 in $\mathbf{1 1}$ was changed into an acetate in 4, which was supported by HMBC correlations from $\mathrm{H}_{2}-15$ to carboxyl carbon (Fig. 3). Similar to 11, a large coupling constant $(J=9.3 \mathrm{~Hz}$ ) between $\mathrm{H}-8$ and $\mathrm{H}-9$ observed for 4, together with NOE cross peaks of $\mathrm{H}-8\left(\delta_{\mathrm{H}} 4.08\right) / \mathrm{H}_{\mathrm{eq}}-5\left(\delta_{\mathrm{H}} 1.90\right)$, and $\mathrm{H}-9\left(\delta_{\mathrm{H}}\right.$ 3.46) $/ \mathrm{H}_{3}-13\left(\delta_{\mathrm{H}} 0.83\right) / \mathrm{H}_{\mathrm{eq}}{ }^{-1}\left(\delta_{\mathrm{H}} 2.07\right) / \mathrm{H}-14\left(\delta_{\mathrm{H}} 4.78\right)$ (Fig. 4), suggested that compound $\mathbf{4}$ is the acetyl derivative of $\mathbf{1 1}$, and they share the same relative configuration at C-6, C-8, and C-9.
In addition, the optical rotation of 4 showed positive sign $\left([\alpha]_{20}\right.$ $\mathrm{D}+45.5)$ similar to of $11\left([\alpha]_{26} \mathrm{D}+79.7\right),{ }^{13}$ leading to the assignment of the absolute stereochemistry of 4 as $6 S, 8 S, 9 S$ (Fig. 1).

The molecular formula of ochracine $\mathrm{J}(5)$, is $\mathrm{C}_{15} \mathrm{H}_{22} \mathrm{O}_{3}$ deduced by HREIMS ion at $m / z 250.1567[\mathrm{M}]^{+}$. The $1 \mathrm{D}$ NMR (Tables 1 and 2) and HSQC spectra displayed signals for three methyl singlets, five methylenes (one oxygenated), an $\alpha, \beta$ unsaturated ketone $\left(\delta_{\mathrm{C}} 170.9 ; \delta_{\mathrm{C} / \mathrm{H}} 127.3 / 5.88\right.$, s; 198.8), one pair of trisubstituted double bond carbons, and two $\mathrm{sp}^{3}$ quaternary carbons. These data shared close similarity to those of acaciicolinol L (10) ${ }^{13}$ which was also isolated from in this study, the only difference between them being the absence of hydroxyl at C-8 in 5. This difference was confirmed by the presence of a singlet olefinic proton $\left(\delta_{\mathrm{H}} 5.88\right)$ and a long-range correlation from $\mathrm{H}_{3}-14$ to $\mathrm{C}-8$ in the HMBC experiment (Fig. 3). Since there is only one chiral carbon, the absolute stereochemistry of C-6 was defined $S$ by comparison of the experimental value of optical rotation $\left([\alpha]_{20 \mathrm{D}}+39.4\right)$ with both the reported data of $\mathbf{1 0}$ $\left([\alpha]_{27 \mathrm{D}}+159.6\right)$ and the calculated data $\left([\alpha]_{\mathrm{D}}+22.3\right)(\mathrm{ESI} \dagger)$. Hence, the structure of 5 was identified as shown in Fig. 1.

Ochracine $\mathrm{K}(6)$, presented a molecular formula $\mathrm{C}_{15} \mathrm{H}_{22} \mathrm{O}_{2}$ based on the HRESIMS (observed $m / z 257.1512[\mathrm{M}+\mathrm{Na}]^{+}$), requiring for five indices of double bond equivalents. The ${ }^{13} \mathrm{C}$ NMR and DEPT spectra of 6 (Table 2) showed 15 carbon signals corresponding to four methyls $\left(\delta_{\mathrm{C}} 21.5,28.3,28.4\right.$, and 29.8), one $\mathrm{sp}^{3}$ methylene $\left(\delta_{\mathrm{C}} 35.6\right)$, three $\mathrm{sp}^{2}$ methines $\left(\delta_{\mathrm{C}} 123.8,126.1\right.$, and 136.5), four $\mathrm{sp}^{3}$ methines $\left(\delta_{\mathrm{C}} 37.1,40.0,51.4\right.$, and 77.3), and three quaternary carbons (one $\mathrm{sp}^{2} \delta_{\mathrm{C}} 138.4$, and two oxygenated $\delta_{\mathrm{C}} 72.9,77.4$ ). The ${ }^{1} \mathrm{H}$ NMR spectrum of 6 (Table 3) displayed signals of four singlet methyl groups at $\delta_{\mathrm{H}} 1.21\left(\mathrm{H}_{3}-15\right), 1.26\left(\mathrm{H}_{3}-\right.$ 13), $1.31\left(\mathrm{H}_{3}-12\right)$, and $1.67\left(\mathrm{H}_{3}-14\right)$, one oxymethine at $\delta_{\mathrm{H}} 4.04(\mathrm{~d}$, $J=5.0 \mathrm{~Hz}, \mathrm{H}-3$ ), three olefinic protons at 4.86 (brs, H-5), 5.66 (dd, $J=10.3,6.2 \mathrm{~Hz}, \mathrm{H}-8), 5.99$ (d, $J=10.3 \mathrm{~Hz}, \mathrm{H}-9$ ). These described NMR characteristic signals and MS data suggested 6 should be a sesquiterpene. Starting from obvious HMBC correlations of $\mathrm{H}_{3}-12 / 13$ to $\mathrm{C}-7 / 11, \mathrm{H}_{3}-14$ to $\mathrm{C}-3 / 4 / 5, \mathrm{H}_{3}-15$ to $\mathrm{C}-1 /$

Table $3{ }^{1} \mathrm{H}$ NMR data of compounds 6 and $7(150 \mathrm{MHz})$

\begin{tabular}{lll}
\hline No. & $\mathbf{6}^{b}$ & $7^{a}$ \\
\hline 1 & $2.60, \mathrm{dd}(4.8,4.8)$ & $3.24, \mathrm{~m}$ \\
2 & $2.21, \mathrm{ddd}(11.0,5.0,4.8)$, & $2.86, \mathrm{dd}(16.3,5.3)$ \\
& $\mathrm{H}_{\mathrm{eq}}, 1.87, \mathrm{~d}(11.0), \mathrm{H}_{\mathrm{ax}}$ & $2.78, \mathrm{dd}(16.3,5.6)$ \\
3 & $4.04, \mathrm{~d}(5.0)$ & \\
5 & $4.86, \mathrm{brs}$ & 6.55, brs \\
6 & $2.93, \mathrm{brs}$ & 3.32, overlapped \\
7 & $1.99, \mathrm{~d}(6.2)$ & $2.17, \mathrm{dd}(8.5,4.3)$ \\
8 & $5.66, \mathrm{dd}(10.3,6.2)$ & \\
9 & $5.99, \mathrm{~d}(10.3)$ & $5.81, \mathrm{brs}$ \\
11 & & $2.02, \mathrm{~m}$ \\
12 & $1.31, \mathrm{~s}$ & $1.14, \mathrm{~d}(7.0)$ \\
13 & $1.26, \mathrm{~s}$ & $0.92, \mathrm{~d}(7.0)$ \\
14 & $1.67, \mathrm{~s}$ & $1.72, \mathrm{~s}$ \\
15 & $1.21, \mathrm{~s}$ & $1.92, \mathrm{~s}$
\end{tabular}

${ }^{a}$ Measured in $\mathrm{CD}_{3} \mathrm{OD} .{ }^{b}$ Measured in $\mathrm{CDCl}_{3}$. 

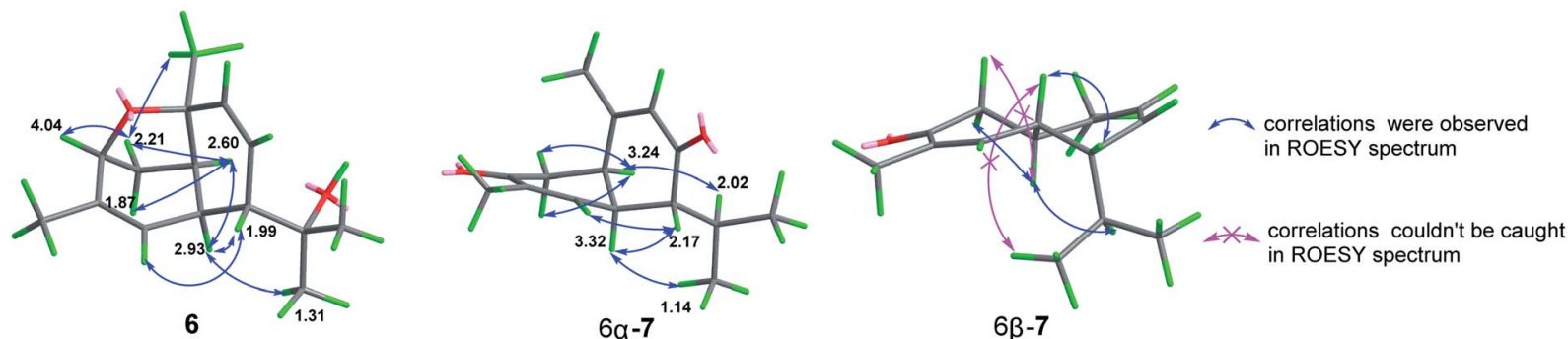

$6 \beta-7$

Fig. 8 Selected NOE correlations of 6 and 7 .

9/10, coupled with the successive ${ }^{1} \mathrm{H}-{ }^{1} \mathrm{H}$ COSY correlations of $\mathrm{H}-$ $3 / \mathrm{H}_{2}-2 / \mathrm{H}-1 / \mathrm{H}-6 / \mathrm{H}-7 / \mathrm{H}-8 / \mathrm{H}-9$ and $\mathrm{H}-5 / \mathrm{H}-6$ (Fig. 3) suggested that 6 is a cadinane with two pair of double bonds at C-4(5) and C$8(9)$, and three oxygen baring carbons (C-3, C-10, and C-11). However, the MS result and the above assignments indicated that $\mathbf{6}$ is tricyclic. Further analysis of HMBC, a key correlation from $\mathrm{H}-3$ to $\mathrm{C}-10$ implied that the third ring is formed between $3-\mathrm{OH}$ and $10-\mathrm{OH}$ via a dehydration reaction. The relative stereochemistry of $6\left(1 S^{*}, 3 R^{*}, 6 R^{*}, 7 R^{*}, 10 R^{*}\right)$ was determined by a combination of JBCA and ROESY spectrum (Fig. 8). Firstly, dihedral angles of $\mathrm{H}-3-\mathrm{C}-3-\mathrm{C}-2-\mathrm{H}_{\mathrm{ax}}-2$ and $\mathrm{H}_{\mathrm{ax}}-2-\mathrm{C}-2-\mathrm{C}-1-\mathrm{H}-1$ close to $90^{\circ}$ deduced by the JBCA $\left(\mathrm{H}-3, \delta_{\mathrm{H}} 4.04, \mathrm{~d}, J=5.0 \mathrm{~Hz}\right.$; $\mathrm{H}_{\mathrm{ax}}{ }^{-2}, \delta_{\mathrm{H}} 1.87, \mathrm{~d}, J=11 \mathrm{~Hz}$ ), together with the correlations of $\mathrm{H}^{-}$ $3 / \mathrm{H}_{2}-2 / \mathrm{H}-1\left(\delta_{\mathrm{H}} 2.60\right), \mathrm{H}_{3}-15 / \mathrm{H}_{\mathrm{eq}}-2\left(\delta_{\mathrm{H}} 2.21\right)$ in the ROESY spectrum (Fig. 8), suggested that the orientations of $\mathrm{H}-1, \mathrm{H}-3$, and $\mathrm{H}_{3}-15$ are $\beta$. The broad singlet signal for H-6 indicative of $90^{\circ}$ dihedral angles between $\mathrm{H}-6$ and other protons at adjacent carbons, coupled NOE cross peaks of $\mathrm{H}-1 / \mathrm{H}-6\left(\delta_{\mathrm{H}} 2.93\right) / \mathrm{H}_{3}-12$ $\left(\delta_{\mathrm{H}} 1.31\right)$, and $\mathrm{H}-7\left(\delta_{\mathrm{H}} 1.99\right) / \mathrm{H}-5\left(\delta_{\mathrm{H}} 4.86\right)$, illustrated that the orientation of $\mathrm{H}-6$ is $\beta$, and the orientation of $\mathrm{H}-7$ is $\alpha$.

By using of the same quantum chemistry mechanic methods as 1-3, ECD of $(1 S, 3 R, 6 R, 7 R, 10 R)-6$ (6a) and ${ }^{13} \mathrm{C}$ NMR of $\left(1 S^{*}, 3 R^{*}, 6 R^{*}, 7 R^{*}, 10 R^{*}\right)-6$ were calculated (ESI $\dagger$ ) to establish its absolute configurations and prove its structure validity, which shared an opposite curve and a highly comparable linear regression $\left(R^{2}=0.9993\right)$ compared with its experimental $\mathrm{CD} /$ NMR spectra (Fig. 9 and 10), respectively, confirming the absolute configurations of 6 are $1 R, 3 S, 6 S, 7 S, 10 S$. And the

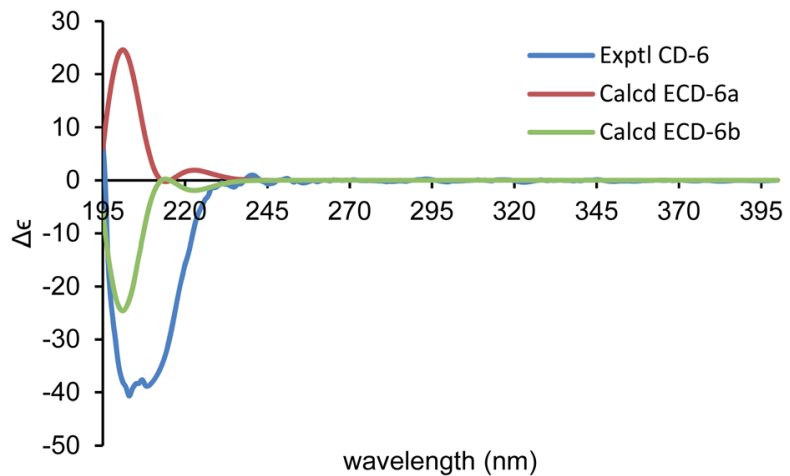

Fig. 9 Comparison of the calculated ECD spectra for $(1 S, 3 R, 6 R, 7 R, 10 R)-6$ (6a) $(\sigma=0.22 \mathrm{eV}$, UV shift $0 \mathrm{~nm})$ and $(1 R, 3 S, 6 S, 7 S, 10 S)-6(6 \mathrm{~b})$ with the experimental spectrum of 6 in $\mathrm{MeOH}$. structure of 6 is $(1 R, 3 S, 6 S, 7 S, 10 S)$-amorpha- $5 \alpha, 10 \alpha$-epoxy4(5),8(9)-dien-11-ol.

Ochracine L (7), was obtained as a colourless oil, and its molecular formula, $\mathrm{C}_{15} \mathrm{H}_{20} \mathrm{O}_{2}$, was determined from the HREIMS (observed $\mathrm{m} / \mathrm{z} 232.1466[\mathrm{M}]^{+}$), requiring six degrees of unsaturation. The UV spectrum of 7 presented maximal absorption at 230.5 , and $248.0 \mathrm{~nm}$ implying a conjugated group. Combined analyses of ${ }^{1} \mathrm{H},{ }^{13} \mathrm{C}$, and HSQC data of 7 (Tables 2 and 3) revealed the presence of two down-shifted methyl singlets and two secondary methyls, one $\mathrm{sp}^{3}$ methylene, two $\mathrm{sp}^{2}$ and four $\mathrm{sp}^{3}$ methines, five quaternary carbons (two conjugated ketones, two olefinic carbons). Since the two ketones and two double bonds takes up 4 degrees of hydrogen deficiency, 7 should be bicyclic. The existence of a propyl unit supported by
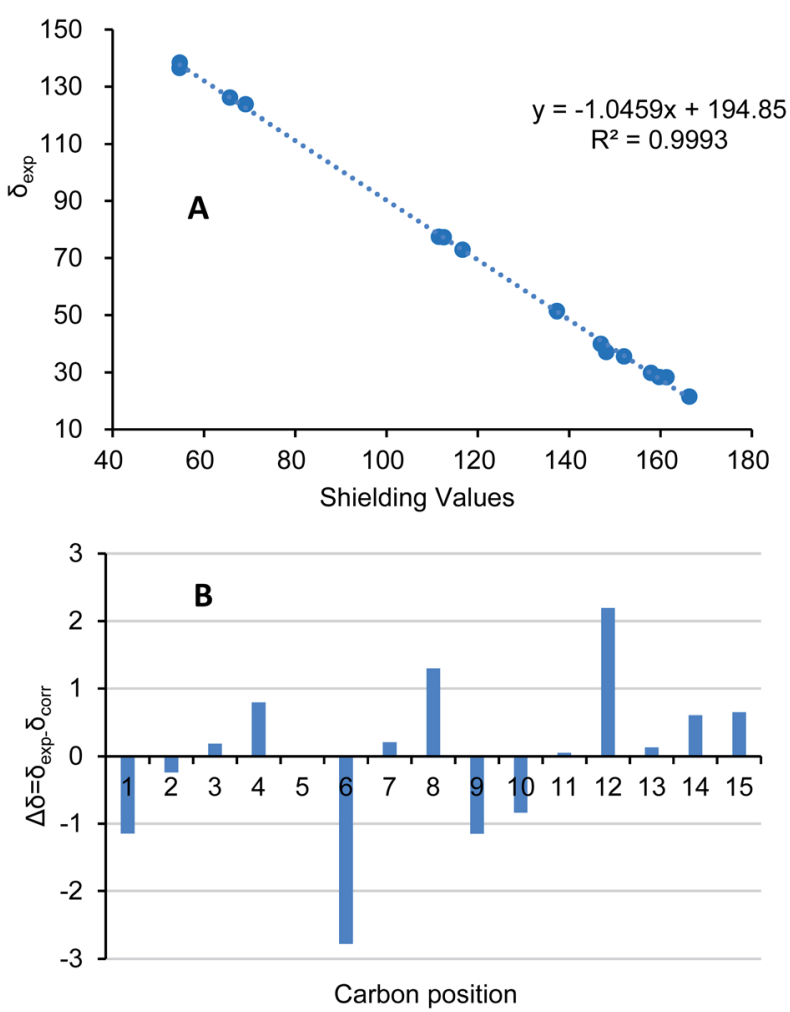

Fig. 10 (A) Regression analysis of experimental versus calculated ${ }^{13} \mathrm{C}$ NMR chemical shifts of 6 at GIAO B3LYP/6-31G(d) level; linear fitting was shown as a line. (B) Relative chemical shift errors between scaled ${ }^{13} \mathrm{C}$ NMR and experimental ${ }^{13} \mathrm{C}$ NMR for 6. 

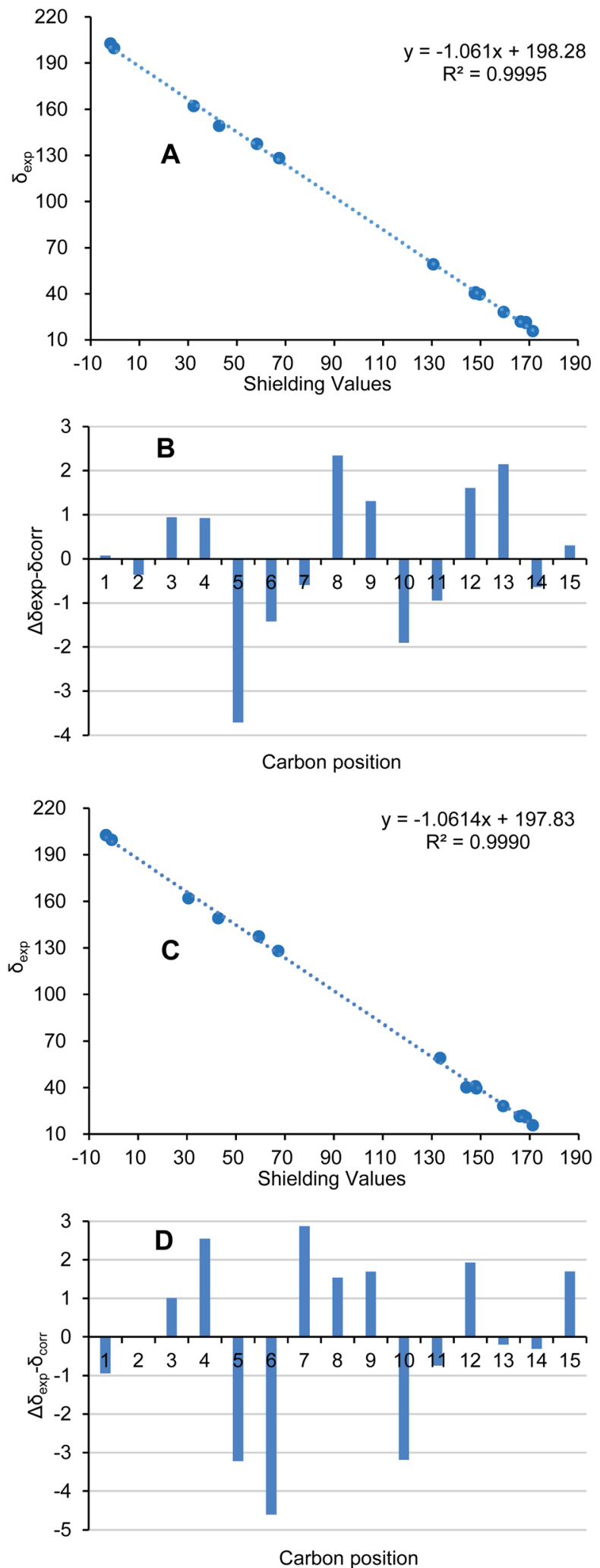

Fig. 11 (A/C) Regression analysis of experimental versus calculated ${ }^{13} \mathrm{C}$ NMR chemical shifts of $6 \alpha-7 / 6 \beta-7$ at GIAO B3LYP/6-31G(d) level. (B/D) Relative chemical shift errors between scaled ${ }^{13} \mathrm{C}$ NMR and experimental ${ }^{13} \mathrm{C}$ NMR for $6 \alpha-7 / 6 \beta-7$.
${ }^{1} \mathrm{H}-{ }^{1} \mathrm{H}$ COSY (Fig. 3) correlations between $\mathrm{H}_{3}-12 / \mathrm{H}-11 / \mathrm{H}_{3}-13$ indicated that this bicyclic molecule is a cadinane-type sesquiterpene, and shared close similarity to $\alpha$-amorphene-3-one, ${ }^{22}$ except the presence of an additional conjugated ketone $\left(\delta_{\mathrm{C}}\right.$ 202.6) at C-8 in 7 rather than $8-\mathrm{CH}_{2}$ in $\alpha$-amorphene-3-one. The relative configuration of 7 was mainly assigned by ROESY spectrum. Correlations of $\mathrm{H}-1\left(\delta_{\mathrm{H}} 3.24\right) / \mathrm{H}-11\left(\delta_{\mathrm{H}} 2.02\right)$ suggested that $\mathrm{H}-1$ and $\mathrm{H}-7$ are in opposite side. It was difficult to deduce the relative configuration of $\mathrm{H}-6$ by NOE correlation and JBCA analysis due to the close chemical shifts of $\mathrm{H}-1$ and $\mathrm{H}-6$, and the partially overlapped signal of H-6. Therefore, NOE correlations of the two possible stereoisomers, $6 \alpha-/ 6 \beta-7$, were compared. As shown in Fig. 8, only the $6 \alpha-7$ can satisfy these NOE correlations of $\mathrm{H}_{2}-2 / \mathrm{H}-1$, and $\mathrm{H}_{3}-12 / \mathrm{H}-6 / \mathrm{H}-7$, so the relative configurations of 7 are $1 R^{*}, 6 S^{*}, 7 R^{*}(6 \alpha-7)$. To further ensure this deduction that the structure of 7 is $6 \alpha-7$ other than $6 \beta-7$, their ${ }^{13} \mathrm{C}$ NMR were calculated as shown in Fig. 11 (ESI†). Obviously, $6 \beta-7$ could be excluded by the $R^{2}$ value $\left(6 \alpha-7, R^{2}=0.9995 ; 6 \beta-7, R^{2}=0.9990\right)$.

Considering the biosynthetic pathway and the calculated optical rotation $\left([\alpha]_{\mathrm{D}}+83.2\right)$ of $6 \alpha-7$ (ESI $\left.\dagger\right)$, the absolute configurations of 7 were assigned as $1 R, 6 S, 7 R$. Thus, the structure of 7 is $(1 R, 6 S, 7 R)$-amorpha-4,9(10)-diene-3,8-dione.

The structures of merulinol (8), acaciicolinols C (9), L (10), and F (11) were established by comparing the NMR data with the published values. ${ }^{11,13}$

All the new isolates (1-7) were tested for their cytotoxicity against five human cancer cell lines: HL-60, SMMC-7721, A549, MCF-7, and SW-480, and against nitric oxide (NO) production. Unfortunately, they were devoid of any cytotoxicity and NOproduction inhibitory activity.

\section{Conclusions}

In summary, eleven sesquiterpenes, including nine chamigrane-type ones and two cadinane-type ones, were isolated from the fermentation broth of the basidiomycete $S$. ochraceum. Their planar structures and absolute stereostructures were elucidated by spectroscopic analysis and calculated methods. Compounds $\mathbf{1}$ and $\mathbf{6}$, each featured by a six or five-membered ether ring with the absolute configurations established via a single X-ray diffraction experiment and/or computational methods, are quite novel tricyclic sesquiterpene in the chamigrane or cadinane families. All the new isolates were evaluated for their cytotoxicity against five cancer cell lines and inhibition against NO production. One case should be noted is that the reason fails to obtain endoperoxide chamigranes may be attributed to the culture medium used for $S$. ochraceum. It was suggested that potato dextrose broth $(\mathrm{PDB})^{2,3,13,14}$ is more suitable for production of the endoperoxide chamigranes than sabouraud dextrose broth (SDB) ${ }^{11}$ or glucose peptone broth (GPB) used in this research.

\section{Experimental section}

\section{General experimental procedures}

The crystal data were collected on an APEX II DUO spectrophotometer (Bruker AXS GmbH, Karlsruhe, Germany) using 
graphite-monochromated $\mathrm{Cu} \mathrm{K} \alpha$ radiation $(\lambda=1.54178 \AA)$ as the X-ray source. Melting point was measured on an X-4 microscopic melting point meter (Yuhua Instrument Co., Ltd, Gongyi, China). Optical rotations were obtained on a JASCOP1020 digital polarimeter (Horiba, Kyoto, Japan). UV spectra were recorded on a Shimadzu UV-2401PC UV-visible recording spectrophotometer (Shimadzu, Kyoto, Japan). A Chiral scan circular dichroism spectrometer (Applied Photophysics Limited, Leatherhead, Surrey, UK) was used to record the CD spectra. 1D and 2D NMR spectra were obtained on a Bruker Avance III $600 \mathrm{MHz}$ spectrometer (Bruker Corporation, Karlsruhe, Germany). An Agilent 6200 Q-TOF MS system (Agilent Technologies, Santa Clara, CA) was used to acquire the HRESIMS data. HREIMS were recorded on a Waters AutoSpec Premier P776 MS system. Sephadex LH-20 (Amersham Biosciences, Uppsala, Sweden) and silica gel (Qingdao Haiyang Chemical Co., Ltd) were used for column chromatography (CC). Medium pressure liquid chromatography (MPLC) was performed on a Büchi Sepacore System equipped with pump manager C-615, pump modules C-605 and fraction collector C660 (Büchi Labortechnik AG, Flawil, Switzerland), and columns packed with Chromatorex C-18 (40-75 $\mu \mathrm{m}$, Fuji Silysia Chemical Ltd., Kasugai, Japan). Preparative high performance liquid chromatography (prep-HPLC) was performed on an Agilent 1260 liquid chromatography system equipped with Zorbax SBC18 columns (particle size $5 \mu \mathrm{m}$, dimensions $9.4 \mathrm{~mm} \times 150$ $\mathrm{mm}$, flow rate $8 \mathrm{~mL} \mathrm{~min}^{-1}$ ) and a DAD detector (Agilent Technologies, Santa Clara, CA, USA).

\section{Fungal material}

The basidiomycete Steccherinum ochraceum was collected at Ailao Mountain of Yunnan Province, China, in July 2003, which was identified by Prof. Mu Zang (Kunming Institute of Botany). The voucher specimen was deposited in the Herbarium of Kunming Institute of Botany, CAS. The strain (HFG119) was isolated from the fresh fruiting bodies of $S$. ochraceum and preserved on potato dextrose agar (PDA) medium at 4 Celsius degree.

\section{Fermentation, extraction and isolation}

The fungus $S$. ochraceum was cultured on PDA medium for one week in the early stage. The agar was then inoculated into $500 \mathrm{~mL}$ of glucose peptone broth (GPB). ${ }^{23}$ After incubation for 1 week at $25{ }^{\circ} \mathrm{C}$, the seed liquid was then inoculated into $500 \mathrm{~mL}$ Erlenmeyer flasks (150 flasks in all), each containing $400 \mathrm{~mL}$ of GPB. After incubation for 21 days, fungal culture was filtered to separate mycelia and broth (total volume of $60 \mathrm{~L}$ ). The culture broth of S. ochraceum (60 L) was filtered and evaporated under reduced pressure, then partitioned between ethyl acetate (EtOAc) and water four times to yield a broth extract. The mycelia were extracted by EtOH (95\%) three times. The extract was evaporated and then partitioned between EtOAc and water four times to give an EtOAc layer. Totally, the weight of the crude EtOAc layer was $34 \mathrm{~g}$.

The crude EtOAc layer was first separated by MPLC eluted with a gradient solvent system of $\mathrm{MeOH}: \mathrm{H}_{2} \mathrm{O}$ (V/V 20 : 80,
$40: 60,60: 40,80: 20,100: 0$ ), which gives twenty-one fractions (A-U). All compounds were purified by preparative HPLC (a flow rate of $8 \mathrm{~mL} \mathrm{~min}^{-1}$ ) with Zorbax SB-C18 column using a linear elution of $\mathrm{MeCN}: \mathrm{H}_{2} \mathrm{O}$ under different volume ratio.

Fraction K (210 mg) was fractionated by Sephadex LH-20 $(\mathrm{MeOH})$ to produce six subfractions (K1-K6). Fractions K3 (73.5 mg), K4 (58.3 mg), and K5 (42.9 mg) were separately subjected to silica gel CC (a gradient solvent system of petroleum ether: acetone (V/V) $5: 1$ to $2: 1)$ to yield thirteen fractions K3a$\mathrm{K} 3 \mathrm{~m}$, ten fractions $\mathrm{K} 4 \mathrm{a}-\mathrm{K} 4 \mathrm{j}$, and ten fractions $\mathrm{K} 5 \mathrm{a}-\mathrm{K} 5 \mathrm{j}$. Compounds 1 ( $\left.3.5 \mathrm{mg}, t_{R}=6.0 \mathrm{~min}\right)$, and $10\left(5.0 \mathrm{mg}, t_{R}=10.8\right.$ min) were purified by semi-preparative HPLC (MeCN : $\mathrm{H}_{2} \mathrm{O}$ $(20: 80 \rightarrow 40: 60)$ in $25 \mathrm{~min}$ ) from fraction K4b. Similarly, subfractions $\mathrm{K} 3 \mathrm{~g}$ (MeCN : $\mathrm{H}_{2} \mathrm{O}(17: 83 \rightarrow 32: 68)$ in $20 \mathrm{~min}$ ), $\mathrm{K} 3 \mathrm{~b}\left(\mathrm{MeCN}: \mathrm{H}_{2} \mathrm{O}(17: 83 \rightarrow 32: 68)\right.$ in $\left.20 \mathrm{~min}\right)$ and $\mathrm{K} 3 \mathrm{l}$ $\left(\mathrm{MeCN}: \mathrm{H}_{2} \mathrm{O}(17: 83 \rightarrow 28: 72)\right.$ in $\left.20 \mathrm{~min}\right)$ were dealt on semipreparative HPLC affording compounds 5 (1.4 mg, $t_{R}=15.0$ $\mathrm{min}), 7\left(2.1 \mathrm{mg}, t_{R}=18.9 \mathrm{~min}\right)$ and $11\left(6.1 \mathrm{mg}, t_{R}=14.7 \mathrm{~min}\right)$, respectively. Compound 9 (3.6 $\mathrm{mg}, t_{R}=7.8 \mathrm{~min}$ ) was isolated from fraction $\mathrm{K} 5 \mathrm{~b}\left(\mathrm{MeCN}: \mathrm{H}_{2} \mathrm{O}(20: 80 \rightarrow 40: 60)\right.$ in $\left.25 \mathrm{~min}\right)$ by preparative HPLC (a flow rate of $8 \mathrm{~mL} \mathrm{~min}^{-1}$ ) with Zorbax SBC18 column.

Subsequently, fraction L (190 mg) was further purified on Sephadex $\mathrm{LH}-20\left(\mathrm{CH}_{3} \mathrm{OH}\right)$ affording three subfractions (L1-L3). Fraction L2 (80.9 mg) was subjected to Sephadex LH-20 (acetone) to give seventeen subfractions (L2a-L2q). By using preparative HPLC (a flow rate of $8 \mathrm{~mL} \mathrm{~min}^{-1}$ ) with Zorbax SBC18 column, compound 6 (1.0 mg, $t_{R}=11.3 \mathrm{~min}, \mathrm{MeCN}: \mathrm{H}_{2}$ $\mathrm{O}(18: 82 \rightarrow 30: 70)$ in $20 \mathrm{~min}$ ) was purified from L2d, and compound $8\left(5.4 \mathrm{mg}, t_{R}=17.0 \mathrm{~min}\right)$ from $\mathrm{L} 2 \mathrm{n}\left(\mathrm{MeCN}: \mathrm{H}_{2} \mathrm{O}\right.$ $(24: 76 \rightarrow 39: 61)$ in $20 \mathrm{~min})$.

Fractions $\mathrm{M}(160 \mathrm{mg})$ and $\mathrm{O}(113 \mathrm{mg})$ were further purified by Sephadex LH-20 twice in succession $\left(\mathrm{CH}_{3} \mathrm{OH}\right.$ and then acetone). Fractions $\mathrm{M} 2$ and $\mathrm{O} 1$ gave 7 (M2a- M2g) and 8 minor fractions (O1a-O1h), among them subfractions M2f (MeCN : $\mathrm{H}_{2} \mathrm{O}(20: 80$ $\rightarrow 33: 67)$ in $20 \mathrm{~min}$ ) yielding compounds $2\left(1.0 \mathrm{mg}, t_{R}=17.0\right.$ $\min )$ and $3\left(1.1 \mathrm{mg}, t_{R}=17.5 \mathrm{~min}\right)$, and subfractions M2f $\left(\mathrm{MeCN}: \mathrm{H}_{2} \mathrm{O}(20: 80 \rightarrow 35: 65)\right.$ in $20 \mathrm{~min}$ ) yielding compound $4\left(5.0 \mathrm{mg}, t_{R}=17.0 \mathrm{~min}\right.$ ) by preparative HPLC (a flow rate of 8 $\mathrm{mL} \min ^{-1}$ ) with Zorbax SB-C18 column.

Ochracine F (1). Colourless needles; $[\alpha]_{20} \mathrm{D}+47.9$ (c 0.35 $\mathrm{MeOH})$; m.p. 146.6-153.6 ${ }^{\circ} \mathrm{C}$; UV (MeOH) $\lambda_{\max } \mathrm{nm}(\log \varepsilon): 214.2$ (3.90); ${ }^{1} \mathrm{H}$ NMR (600 MHz CD $\left.3 \mathrm{OD}\right)$ data (Table 1$) ;{ }^{13} \mathrm{C}$ NMR (150 $\mathrm{MHz} \mathrm{CD} \mathrm{CD}_{3} \mathrm{OD}$ ) data (Table 2); HRESIMS $m / z$ 289.1408 [M $\left.+\mathrm{Na}\right]^{+}$ (calcd for $\mathrm{C}_{15} \mathrm{H}_{22} \mathrm{O}_{4} \mathrm{Na}, 289.1410$ ).

$\mathrm{X}$-ray crystallographic analysis. Colourless crystal of 1 were obtained by crystallization from $\mathrm{MeOH}$. Crystal data for $\mathrm{Cu}_{-} \mathbf{1} \_0$ $\mathrm{m}: 2\left(\mathrm{C}_{15} \mathrm{H}_{22} \mathrm{O}_{4}\right) \cdot 3\left(\mathrm{H}_{2} \mathrm{O}\right) \quad M=586.70 a=6.1285(5) \AA$ 32.973(3) $\AA \mathrm{\circ} c=7.7602(6) \AA \circ \alpha=90^{\circ} \beta=108.863(3)^{\circ} \gamma=90^{\circ} \mathrm{V}=$ 1483.9(2) $\AA^{3} T=100(2) \mathrm{K}$ space group $P 21 Z=2 \mu(\mathrm{CuK} \alpha)=0.819$ $\mathrm{mm}^{-1} 13461$ reflections measured 4805 independent reflections $\left(R_{\text {int }}=0.0459\right)$. The final $R_{1}$ values were $0.0579(I>2 \sigma(I))$. The final $w R\left(F^{2}\right)$ values were $0.1595(I>2 \sigma(I))$. The final $R_{1}$ values were 0.0615 (all data). The final $w R\left(F^{2}\right)$ values were 0.1664 (all data). The goodness of fit on $F^{2}$ was 1.049. Flack parameter $=$ $0.14(8)$. 
Ochracine G (2). White powder; $[\alpha]_{19 \mathrm{D}}-52.8($ c $0.06 \mathrm{MeOH})$; ${ }^{1} \mathrm{H}$ NMR (600 MHz $\mathrm{CDCl}_{3}$ ) data (Table 1$) ;{ }^{13} \mathrm{C}$ NMR $(0.150 \mathrm{MHz}$ $\mathrm{CDCl}_{3}$ ) data (Table 2); HRESIMS $m / z 273.1467[\mathrm{M}+\mathrm{Na}]^{+}$(calcd for $\left.\mathrm{C}_{15} \mathrm{H}_{22} \mathrm{O}_{3} \mathrm{Na} 273.1461\right)$.

Ochracine H (3). White powder; $[\alpha]_{19 \mathrm{D}}-6.1(c 0.11 \mathrm{MeOH})$; $\mathrm{UV}(\mathrm{MeOH}) \lambda_{\max } \mathrm{nm}(\log \varepsilon): 215.6$ (3.97); ${ }^{1} \mathrm{H}$ NMR $(600 \mathrm{MHz}$ $\mathrm{CDCl}_{3}$ ) data (Table 1); ${ }^{13} \mathrm{C}$ NMR (150 $\mathrm{MHz} \mathrm{CDCl}_{3}$ ) data (Table 2); HREIMS $m / z 250.1564[\mathrm{M}]^{+}$(calcd for $\mathrm{C}_{15} \mathrm{H}_{22} \mathrm{O}_{3} 250.1569$ ).

Ochracine I (4). Colourless oil; $[\alpha]_{20 \mathrm{D}}+45.5$ ( c $\left.0.50 \mathrm{MeOH}\right)$; ${ }^{1} \mathrm{H}$ NMR (600 MHz $\mathrm{CDCl}_{3}$ ) data (Table 1); ${ }^{13} \mathrm{C}$ NMR $(150 \mathrm{MHz}$ $\mathrm{CDCl}_{3}$ ) data (Table 2); HRESIMS $m / z 317.1728[\mathrm{M}+\mathrm{Na}]^{+}$(calcd for $\mathrm{C}_{17} \mathrm{H}_{26} \mathrm{O}_{4} \mathrm{Na}$ 317.1723).

Ochracine J (5). Colourless oil; $[\alpha]_{20 \mathrm{D}}+39.4(c$ 0.14 MeOH); $\mathrm{UV}(\mathrm{MeOH}) \lambda_{\max } \mathrm{nm}(\log \varepsilon): 243.8$ (3.95); ${ }^{1} \mathrm{H}$ NMR $(600 \mathrm{MHz}$ $\mathrm{CDCl}_{3}$ ) data (Table 1); ${ }^{13} \mathrm{C}$ NMR $\left(150 \mathrm{MHz}^{\mathrm{CDCl}}{ }_{3}\right.$ ) data (Table 2); HREIMS $m / z 250.1567[\mathrm{M}]^{+}$(calcd for $\mathrm{C}_{15} \mathrm{H}_{22} \mathrm{O}_{3} 250.1569$ ).

Ochracine K (6). Colourless oil; $[\alpha]_{20 \mathrm{D}}+76.5($ c $0.05 \mathrm{MeOH})$; $\mathrm{UV}(\mathrm{MeOH}) \lambda_{\max } \mathrm{nm}(\log \varepsilon): 203.0$ (3.62); ${ }^{1} \mathrm{H}$ NMR $(600 \mathrm{MHz}$ $\mathrm{CDCl}_{3}$ ) data (Table 3); ${ }^{13} \mathrm{C}$ NMR (150 $\mathrm{MHz} \mathrm{CDCl}_{3}$ ) data (Table 2); HRESIMS $m / z$ 257.1512 $[\mathrm{M}+\mathrm{Na}]^{+}$(calcd for $\mathrm{C}_{15} \mathrm{H}_{22} \mathrm{O}_{2} \mathrm{Na}$ 257.1512).

Ochracine L (7). Colourless oil; $[\alpha]_{20 \mathrm{D}}+35.8(c 0.21 \mathrm{MeOH})$; $\mathrm{UV}(\mathrm{MeOH}) \lambda_{\max } \mathrm{nm}(\log \varepsilon): 230.5$ (4.16) 248.0 (3.56); ${ }^{1} \mathrm{H}$ NMR (600 MHz $\mathrm{CD}_{3} \mathrm{OD}$ ) data (Table 3); ${ }^{13} \mathrm{C} \mathrm{NMR}\left(150 \mathrm{MHz} \mathrm{CD}_{3} \mathrm{OD}\right.$ ) data (Table 2); HREIMS $m / z$ 232.1466 [M] $]^{+}$(calcd for $\mathrm{C}_{15} \mathrm{H}_{20} \mathrm{O}_{2}$ 232.1463).

\section{Bioassays}

Nitric oxide production in RAW 264.7 macrophages. The RPMI 1640 medium (Hyclone, Logan, UT) containing 10\% FBS was used to culture the murine monocytic RAW 264.7 macrophages. The compounds were dissolved in DMSO and further diluted in medium to produce different concentrations. The culture medium and cell mixture were dispensed into 96-well plates $\left(2 \times 10^{5}\right.$ cells per well) and maintained at $37^{\circ} \mathrm{C}$ under $5 \%$ $\mathrm{CO}_{2}$ in a humidified atmosphere. After preincubation for $24 \mathrm{~h}$, serial dilutions of the test compounds were added into the cells, up to the maximum concentration of $25 \mu \mathrm{M}$, then LPS was added to a concentration $1 \mu \mathrm{g} \mathrm{mL^{-1 }}$ and incubation continued for $18 \mathrm{~h}$. After addition of $100 \mu \mathrm{L}$ of Griess reagent (reagent A and reagent B, Sigma, St. Louis, Mo) to $100 \mu \mathrm{L}$ of each supernatant from the LPS-treated or LPS- and compound-treated cells in triplicate and incubation for $5 \mathrm{~min}$, NO production of each cell was assessed by sample absorbance at $570 \mathrm{~nm}$ by a 2104 Envision Multilabel plate reader. $\mathrm{L}-N^{\mathrm{G}}$-Monomethyl arginine (LNMMA) was used as a positive control.

Cytotoxicity against five human cancer cell lines. The following five human cancer cell lines were used: the HL-60 (ATCC CCL-240) human myeloid leukemia; SMMC-7721 human hepatocellular carcinoma; A-549 (ATCC CCL-185) lung cancer; MCF-7 (ATCC HTB-22) breast cancer; SW-480 (ATCC CCL-228) human colon cancer. The cell line SMMC-7721 was bought from China Infrastructure of Cell Line Resources (Beijing, China), and others were bought from American Type Culture Collection (ATCC, Manassas, VA). All cells were cultured in RPMI-1640 medium containing 10\% fetal bovine serum (FBS)
(Hyclone) and maintained at $37{ }^{\circ} \mathrm{C}$ under $5 \% \mathrm{CO}_{2}$ in a humidified atmosphere. Colorimetric measurements of the amount of insoluble formazan which was produced in living cells based on the reduction of 3-(4,5-dimethylthiazol-2-yl)-2,5diphenyltetrazolium bromide (MTT) (Sigma, St. Louis, MO) was used to assess cell viability. In brief, each well of a 96-well cell culture plate was seeded with $100 \mu \mathrm{L}$ of adherent cells and kept for $12 \mathrm{~h}$ for adherence, and then added with test compounds, however, suspended cells were seeded before added with test compounds with both the same density of $1 \times$ $10^{5}$ cells per mL every $100 \mu \mathrm{L}$ of culture medium. After different concentrations of test compounds addition, each cancer cell line was incubated for $48 \mathrm{~h}$ in triplicate. Cisplatin was used as a positive control. After the incubation, each well was treated with MTT $(100 \mu \mathrm{g})$ and incubation continued for $4 \mathrm{~h}$ at $37^{\circ} \mathrm{C}$. After the removal of the $100 \mu \mathrm{L}$ culture medium, the cells were lysed with $20 \%$ SDS-50\% DMF $(100 \mu \mathrm{L})$. The remaining lysates were subjected to a measure of optical density at $595 \mathrm{~nm}$ with a 96-well microtiter plate reader. ${ }^{24}$

\section{Quantum chemistry calculation details}

Conformation searches on the candidate structures were performed by MMFF94s force field, giving compounds $(6 R, 7 S, 8 S, 11 R)-1,(6 R, 7 S)-2,(6 S, 7 S)-3$ four possible conformers each, $(6 S)-5$ seven ones, $(1 S, 3 R, 6 R, 7 R, 10 R)-6$ (6a) three ones, $6 \alpha-$ 7 two ones, $6 \beta-7$ three ones with distribution higher than $1 \%$. These conformers were further optimized on B3LYP/6-31g(d) level of theory in Gaussian 16 program, ${ }^{25}$ respectively. The conformers within $3 \mathrm{kcal} \mathrm{mol}^{-1}$ of global minimum energy were selected for further calculations. The ECD spectra and optical rotations for the selected conformers were accomplished by B3LYP/6-31g(d) with CPCM model in methanol. The ECD calculation results were processed on SpecDis v1.71 software, ${ }^{26}$ by which the ECD spectrum of the antipode, such as $(1 R, 3 S, 6 S, 7 S, 10 S)-\mathbf{6}(\mathbf{6 b})$, was generated directly by the function "enantiomeric ECD". The calculated specific optical rotation data of these conformers were averaged according to the Boltzmann distribution theory and their relative Gibbs free energy. The NMR calculations were carried out by B3LYP/6$31 \mathrm{~g}(\mathrm{~d})$ level of GIAO theory. The NMR calculation were processed by Microsoft Office Excel program (ESI $\dagger$ ).

\section{Author contributions}

Z. Z. Zhao performed the experiments, data analysis, and experimental planning. H. P. Chen contributed to the calculation work. Q. L. Zhao screened the biological activities. The project was conceived, planned, and supervised by H. P. Chen. and J. K. Liu. The manuscript was written by Z. Z. Zhao, H. P. Chen, and J. K. Liu. All authors reviewed the manuscript.

\section{Conflicts of interest}

There are no conflicts to declare. 


\section{Acknowledgements}

This work was financially supported by the National Natural Science Foundation of China (grant numbers 82003607, 81903512), the Natural Science Foundation of Hubei Province (grant number 2019CFB379), the Research Project on Chinese Medicine Science in Henan Province (grant number 2021ZY1039), and the Key Scientific Research Projects of Universities of Henan Province (grant number 21A360002).

\section{Notes and references}

1 H. P. Chen and J. K. Liu, Progress in the Chemistry of Organic Natural Products, ed. A. D. Kinghorn, H. Falk, S. Gibbons and J. Kobayashi, Springer Publishing AG Switzerland, 2017, vol. 106, p. 1.

2 D. Z. Liu and M. H. Luo, Fitoterapia, 2010, 81, 1205.

3 D. Z. Liu, Z. J. Dong, F. Wang and J. K. Liu, Tetrahedron Lett., 2010, 51, 3152.

4 X. Q. Yu, C. S. Jiang, Y. Zhang, P. Sun, T. Kurtán, A. Mándi, X. L. Li, L. G. Yao, A. H. Liu, B. Wang, Y. W. Guo and S. C. Mao, Phytochemistry, 2017, 136, 81.

5 I. Brito, M. Cueto, A. R. Díaz-Marrero, J. Darias and A. S. Martín, J. Nat. Prod., 2002, 65, 946.

6 D. Davyt, R. Fernandez, L. Suescun, A. W. Mombrú, J. Saldaña, L. Domínguez, J. Coll, M. T. Fujii and E. Manta, J. Nat. Prod., 2001, 64, 1552.

7 J. Kimura, N. Kamada and Y. Tsujimoto, Bull. Chem. Soc. Jpn., 1999, 72, 289.

8 S. M. Al-Massarani, Nat. Prod. Chem. Res., 2014, 2, 1000147.

9 S. Chokpaiboon, D. Sommit, T. Teerawatnanond, N. Muangsin, T. Bunyapaiboonsri and K. Pudhom, J. Nat. Prod., 2010, 73, 1005.

$10 \mathrm{~S}$. Chokpaiboon, D. Sommit, T. Bunyapaiboonsri, K. Matsubara and K. Pudhom, J. Nat. Prod., 2011, 74, 2290.

11 C. Siwattra, T. Thapong, M. Tohru and P. Khanitha, Mar. Drugs, 2016, 14, 132.

12 H. Li, H. Huang, C. Shao, H. Huang, J. Jiang, X. Zhu, Y. Liu, L. Liu, Y. Lu, M. Li, Y. Lin and Z. She, J. Nat. Prod., 2011, 74, 1230.

13 M. Wibowo, V. Prachyawarakorn, T. Aree, C. Mahidol, S. Ruchirawat and P. Kittakoop, Phytochemistry, 2016, 122, 126.
14 M. Wibowo, V. Prachyawarakorn, T. Aree, S. Wiyakrutta, C. Mahidol, S. Ruchirawat and P. Kittakoop, Eur. J. Org. Chem., 2014, 2014, 3976.

15 M. Bu, B. Yang and L. Hu, Curr. Med. Chem., 2016, 23, 383.

16 M. Jung, H. Kim, K. Lee and M. Park, Mini-Rev. Med. Chem., 2003, 3, 159.

17 D. Z. Liu and J. K. Liu, Nat. Prod. Bioprospect., 2013, 3, 161.

18 Z. Z. Zhao, W. S. Feng, X. B. Liang, G. M. Xue, Y. Y. Si, H. P. Chen and J. K. Liu, Fitoterapia, 2019, 139, 104362.

19 R. N. Lawrence, Drug Discov. Today, 1999, 4, 449.

20 Y. Zhang, X. M. Li, Z. Shang, C. S. Li, N. Y. Ji and B. G. Wang, J. Nat. Prod., 2012, 75, 1888.

21 X. M. Zhou, C. J. Zheng, G. Y. Chen, X. P. Song, C. R. Han, G. N. Li, Y. H. Fu, W. H. Chen and Z. G. Niu, J. Nat. Prod., 2014, 74, 2021.

22 Y. Ohta and Y. Hirose, Bull. Chem. Soc. Jpn., 1973, 46, 1535. 23 Z. Z. Zhao, K. Zhao, H. P. Chen, X. Bai, L. Zhang and J. K. Liu, Phytochemistry, 2018, 147, 21.

24 H. P. Chen, Z. Z. Zhao, Z. H. Li, Z. J. Dong, K. Wei, X. Bai, L. Zhang, C. N. Wen, T. Feng and J. K. Liu, ChemistryOpen, 2016, 5, 142.

25 M. J. Frisch, G. W. Trucks, H. B. Schlegel, G. E. Scuseria, M. A. Robb, J. R. Cheeseman, G. Scalmani, V. Barone, G. A. Petersson, H. Nakatsuji, X. Li, M. Caricato, A. V. Marenich, J. Bloino, B. G. Janesko, R. Gomperts, B. Mennucci, H. P. Hratchian, J. V. Ortiz, A. F. Izmaylov, J. L. Sonnenberg, D. Williams-Young, F. Ding, F. Lipparini, F. Egidi, J. Goings, B. Peng, A. Petrone, T. Henderson, D. Ranasinghe, V. G. Zakrzewski, J. Gao, N. Rega, G. Zheng, W. Liang, M. Hada, M. Ehara, K. Toyota, R. Fukuda, J. Hasegawa, M. Ishida, T. Nakajima, Y. Honda, O. Kitao, H. Nakai, T. Vreven, K. Throssell, J. A. Montgomery, Jr., J. E. Peralta, F. Ogliaro, M. J. Bearpark, J. J. Heyd, E. N. Brothers, K. N. Kudin, V. N. Staroverov, T. A. Keith, R. Kobayashi, J. Normand, K. Raghavachari, A. P. Rendell, J. C. Burant, S. S. Iyengar, J. Tomasi, M. Cossi, J. M. Millam, M. Klene, C. Adamo, R. Cammi, J. W. Ochterski, R. L. Martin, K. Morokuma, O. Farkas, J. B. Foresman and D. J. Fox, Gaussian 16, Revision B.01, Gaussian, Inc., Wallingford CT, 2016.

26 T. Bruhn, A. Schaumlöffel, Y. Hemberger and G. Pecitelli. SpecDis version 1.71, Berlin, Germany, 2017, https:/specdissoftware.jimdo.com. 